\title{
The evolution of European bailout arrangements and its impact on sovereign bond yields in the aftermath of the euro crisis
}

\author{
ESZTER BOROS* (1) and GÁBOR SZTANÓ
}

Institute of Finance, Accounting and Business Law, Corvinus University of Budapest, Hungary

Received: May 3, 2020 • Revised manuscript received: August 4, 2020 • Accepted: September 15, 2020

Published online: November 3, 2020

(c) 2020 The Author(s)

\section{ABSTRACT}

The 2010-2012 euro crisis prompted a wave of institutional reforms in the European Economic and Monetary Union (EMU), and one of the most remarkable changes was the creation of a permanent bailout facility for troubled sovereigns. The birth of the European Stability Mechanism (ESM) in 2012 was preceded by harsh debates, reflecting a conflict between a German view of country-level responsibility and FrenchItalian calls for more risk sharing. These tensions have remained ever since, which was also highlighted by conflicts regarding the ESMs overhaul at the end of 2019. Concerns of Italy then drew attention to the fact that a wide range of issues prevented the community from finalizing the post-crisis structure of the eurozone. This paper focuses on the evolution of the EMU financial assistance framework up until the latest efforts for its reform. We analyse the impact of related policy announcements on changes in sovereign bond yields of Italy, Spain, Portugal and Ireland (i.e. the most vulnerable countries during the euro crisis). Our findings show that news on bailout arrangements significantly contributed to a contemporaneous moderation of periphery bond yields, especially in the case of shorter maturities. This result hints at the role of common facilities in supporting financial stability. To enhance this feature, a 'package approach' (i.e. multiple reforms together, as stressed by Italy) may well need to be considered. Such a broad perspective can help strengthen the euro area once the acute threat of the coronavirus pandemic is averted.

\section{KEYWORDS}

euro area, bailout, European Stability Mechanism, reform, Italy, bond yields

\section{JEL-CODES}

F34, F45, G12

\footnotetext{
Corresponding author E-mail: eszter.boros@uni-corvinus.hu
} 


\section{INTRODUCTION}

Tensions in Italy in December 2019 revealed concerns about one of the ongoing institutional reforms of the euro area. Doubts over the intended changes in the European Stability Mechanism (ESM) were voiced by Italy in the final phase of approval. This sheds light on a deeper disagreement among EMU members on the directions that key reforms should take. The debate on the ESM overhaul is all the more crucial as this reform could be one of the few major institutional changes completed since 2014. The new coronavirus crisis, the most recent episode in the history of European crisis management may also draw attention to the importance of sound common action.

As the debate on the ESM can be a turning point, we deem it essential to review the ESMs 'track record' in contributing to financial stability. This issue is closely related to sovereign bond markets, not just because the ESM is mandated to assist states, but also because Italian critics of the reform envisaged a rise in bond yields. (Concerns were related to changes which would make debt restructuring easier.)

Hence, our paper seeks to examine the relationship between government bond yields and bailout-/ESM-related events since the onset of the euro crisis in 2010. Specifically, we investigate whether announcements about rescue funds impacted contemporaneous market sentiments, i.e. whether they prompted immediate changes in periphery bond yields. (As conventional in the literature, the term 'periphery' is used to refer to the Mediterranean member states and Ireland. These sovereigns are of special interest as they suffered the largest spikes in bond yields during the euro crisis.) This research can help reveal whether the creation and usage of the new bailout facilities could contribute to avert threats to financial stability in the euro area at critical moments.

Applying an event study approach, we create an event set which includes announcements about the EMU bailout framework, along with actual cases of financial assistance. This event set is then used in panel regressions to check its possible impact on yields of periphery bonds with different maturities. As we seek to reveal prompt market reactions, we choose to analyse 3-day time periods for each event. Other factors effective in these periods are controlled by different macro indices and variables. Robustness checks are also carried out.

Our results suggest that ESM-related events had a significant negative impact on contemporaneous yields. This finding might indicate the overall stabilizing role of EMU bailout arrangements. The result may serve as a common ground for debates on ESM settings as well as on a set of broader financial reforms. These discussions might end up with the conclusion that a wider range of parallel changes is necessary to preserve the advantages of the ESM. Our contribution to this debate can be regarded as new especially in terms of its coverage of ESMrelated events. Namely, we do not only examine bailouts themselves, but a broad array of announcements about the related institutional progress.

The paper is structured as follows. Chapter 2 provides background with a focus on motivations leading up to the creation and reform of the ESM. Our interpretation aims to understand the possible role of bailouts in the context of a monetary union and also to spot the key events as a basis for our detailed event set. Chapter 3 describes this set, along with the methodology, data and variables used to produce model outputs. Results and limitations are discussed subsequently. Chapter 4 concludes and adds an outlook highlighting the connection between EMU reforms and the economic fallout of the coronavirus pandemic. 


\section{THE EUROPEAN STABILITY MECHANISM: BACKGROUND, CREATION AND REFORM}

Like all major changes in the EMUs institutional architecture during the last couple of years, the creation of a common bailout fund was also triggered by the euro crisis. At the time when Greece's severe debt problem quickly raised market tensions in 2010, the euro area had neither any crisis management functions or framework, nor dedicated financial resources to assist its troubled members. In fact, up until the crisis, several years had passed in the belief that sovereigns in a monetary union could not go bankrupt (Benczes 2011; Surányi 2012), if for no other reason than because their peers would help them 'get through'. This view was not only out of line with the 'no-bailout clause' enshrined in EU treaties, it was also inconsistent with the lack of a proper 'lender of last resort' function on the part of the European Central Bank (ECB) (see De Grauwe 2012; 2013). Nonetheless, the introduction of the euro prompted a substantial reduction in perceived risks, compressing bond spreads for all member countries. This kind of euro-related confidence, together with several macro and policy factors (e.g. ample liquidity in global financial markets, excessive risk-taking), contributed to a prolonged period in which EMU sovereigns could borrow at historically low interest rates. Some of them (Greece and Italy) went on piling up huge debts during the 2000s. In other cases, like Spain and Ireland, private debts increased and ultimately became a 'contingent liability' of sovereigns, in an embrace between banks and states (Acharya et al. 2014). Credit was mostly channelled to domestic consumption and the real estate sector, fuelling asset price bubbles. Thus, burgeoning debts did not come with a similar rise in productivity, which resulted in a loss of competitiveness, and consequently, rising current account deficits of the periphery (see e.g. Strauch et al. 2016).

Market sentiments then drastically changed in late 2009 when these intra-EMU imbalances were put under the spotlight (Giordano et al. 2013; Schwendner et al. 2015). Yields of the Mediterranean states and Ireland soared, not least because prospects of any bailout or fresh liquidity seemed totally uncertain. Anxiety was fuelled by the perception of an extremely fragile EMU framework (Verdun 2015), which left sovereigns without any backstop for their debts akin to foreign exchange liabilities. As De Grauwe $(2012,2013)$ points out, membership in a monetary union involves losing full control of the legal tender. In other words, there is not even an implicit guarantee that money will always be available to pay off creditors. This is because the influence on money supply is in the hands of the single central bank of the currency area, allowing no substantive room for unilateral action. In contrast, 'standalone' states can practically repay any amounts of debts denominated in their own currency at any time. ${ }^{1}$ This of course does not mean that a sovereign default is impossible in this case. (A state in serious trouble would ultimately default on its foreign liabilities and lose access to foreign markets.) Nevertheless, at certain critical moments (like those in 2010 and thereafter), the ability for limitless debt service may make a difference from the viewpoint of investors (see Mehrling 2000 for a discussion on this).

Regarding the sudden stop of market financing in 2010, the problem was not merely that countries in distress had no room for creating euros on their own. Rather, it was about their

${ }^{1}$ Certainly, monetary financing is prohibited in many countries. However, this is ultimately a legal ban which can be practically 'circumvented' or neglected in cases of emergency. 
inability to apply for any last resort (any funds most generally). Neither the ECB nor any other institution were mandated to fulfil such a role (De Grauwe 2012; 2013; Surányi 2012). As regards banks, access to emergency liquidity was possible, but uncertain because it was conditional on ECB action. Note that we do not argue that the spike in periphery bond yields was only attributed to a missing 'lender of last resort' or a deficient institutional framework more broadly. The underlying macro foundations of the troubled countries were certainly poor. It is just suggested here that the pace and amplitude of market reactions were aggravated by the poor architecture of the euro.

As regards an unlimited last resort, it was not until 2012 that the ECB decided to perform such a role. After some previous purchases limited in size and time, the central bank announced to commit itself to infinite intervention in sovereign bond markets. This was hallmarked by the speech of ECB President Mario Draghi who promised to do 'whatever it takes to preserve the euro' (Draghi 2012). Through the subsequent Outright Monetary Transactions (OMT) program, the ECB practically offered to act as a 'lender of last resort' for sovereigns (albeit it did not buy any bonds under the OMT framework, see Strauch et al. 2016). Following the OMT commitment, periphery bond spreads returned to moderate levels, with occasional spikes only (such as in 2015 amid the third phase of the Greek turmoil). The moderation, however, did not come without a price tag in a political sense. Related debates about risk sharing and intra-area 'transfers' were well on the rise. Due to this controversy, the OMT program soon found itself before the German Federal Constitutional Court, being challenged as violating the ban on monetary financing (Várnay 2017). (German reservations were later rejected by the European Court of Justice which acknowledged that the OMT was needed to maintain an effective monetary policy transmission.)

The OMT provides two key insights for our paper. First, it highlights the differences between a German and a French-Italian stance on risk sharing. Bénassy-Quéré et al. 2018 show that Germany, along with the Netherlands and Austria, stresses country-level responsibility and a fear of moral hazard. From this point of view, common financial arrangements and backstops would encourage irresponsible behaviour (e.g. excessive debts) to the detriment of EMU peers. In contrast, other countries led by France, Italy and Spain argue that more risk sharing and stronger cooperation at the union level are necessary to maintain financial stability.

The second 'takeaway' of the OMT is that last resort must be literally unlimited. Capped commitments, such as early interventions by the ECB may not be suited to calm markets, especially in a longer-term perspective. At the beginning of the euro crisis, the introduction of unconventional monetary policy tools was initially limited to maintaining liquidity in the eurosystem and providing long-term financing to EMU banks. Many authors argue that unconventional measures had a significant immediate impact on government bond yields, but in the longer run, capped programs like the Securities Markets Program (SMP) did not provide a long-term solution (Chang - Leblond 2015; Falagiarda - Reitz 2015; Kilponen et al. 2012). Subsequent asset-purchasing schemes, such as the Public Sector Purchase Program (PSPP) and the Asset Purchase Program (APP) were then extended to the entire eurozone, not only the troubled countries.

Such finite backstops may play a key role in the short run, i.e. at critical moments. However, at the onset of the euro crisis, member states could not resort to either dedicated funds for bailouts or any comprehensive crisis management tools. Disagreement on these issues was strong, and tensions have been leaving a mark on the evolution of bailout policies ever since. At start, there was no shared understanding on what a 'bailout' could mean in the EMU framework at all. 
(Remember the 'no bailout clause' which excludes transfers among members.) In the meantime, however, the bankruptcy of one or more member states threatened with 'the mother of all financial crises' (Eichengreen 2010). The situation was further aggravated by the fact that no procedure had been laid down for exiting the monetary union, either. Indeed, membership had been meant to be irreversible (De Grauwe 2018). When a Greek exit started to emerge as a possible option, it was likely to generate unbearable economic and political costs (Eichengreen 2010).

All this market panic forced EMU leaders to come up with bailout packages, providing direct funds for troubled countries. Controversy on financial assistance, however, first caused them to envisage ad hoc commitments only (February 2010). This was well before the realization that a comprehensive framework and the use of the ECBs unlimited intervention power are unavoidable (De Grauwe 2012). A one-time lifebelt for Greece in May 2010 (a loan with strict conditionality, through the ad hoc Greek Loan Facility) could actually be regarded as being in line with the 'no bailout' rule (Micossi et al. 2011; Verdun 2015). For Germany, it could seem well-constrained while also well-suited to stop contagion threatening with bringing down German banks as well. But after a while, bond yields signalled that markets would not be calmed by such a standalone solution. The approach had to be scaled up as soon as the Greek rescue package was signed in May 2010. Thus, the European Financial Stability Facility (EFSF) was created as a temporary vehicle granting emergency credit to troubled sovereigns (up until 2013) (Verdun 2015). The EFSF framework included $€ 60$ billion in loans and credit lines to be provided by the EU budget and further bilateral credit guarantees by members up to $€ 440$ billion. (The former amount is also known as the European Financial Stabilisation Mechanism or shortly, EFSM.) Moreover, the International Monetary Fund (IMF) granted a contribution of $€ 250$ billion (Christova 2011; Gocaj - Meunier 2013). Guarantees were provided by member states on a pro-rata basis, according to their ECB capital keys. This meant that Germany became the biggest potential contributor, able to set the parameters of the institution. The EFSF issued bonds in financial markets to finance bailout commitments. These securities gained high credit rating thanks to the underlying state guarantees with Germany in the first place. Subsequently, the EFSF extended loans to Ireland and Portugal in 2011. Assistance came with widely criticized austerity-based 'reform programs' and near market-interest rates. This was largely due to the fact that Germany wanted to make sure assistance was not a 'subsidy', and no 'Eurobond' was created (Gocaj - Meunier 2013; Verdun 2015). ${ }^{2}$ EFSF principles and procedures drew upon those of the IMF which, along with IMF participation, seemed to be an appropriate 'deterrent' to rule out moral hazard (Pisani-Ferry 2010).

Albeit not unlimited (like an ECB intervention could be), this temporary rescue vehicle was supposed to put an end to market tensions. However, following some favourable reactions, concerns returned due to the actual size of the fund, especially the amount of money readily

\footnotetext{
${ }^{2 ‘}$ Eurobond' refers to a hypothetical mutual debt obligation which EMU members could issue jointly to finance state budgets. Proposals to create such bonds have been common since the start of the euro crisis. See for example Delpla Weizsäcker (2010) or a recent suggestion by nine EMU countries to introduce a 'coronabond' as a response to the catastrophe caused by the COVID-19 pandemic (RTE 2020).

Common bonds, if formally created, would have had lower yields compared to those of periphery sovereign bonds during the 2010-2012 euro crisis. Bonds of EMU bailout funds could be regarded as some kind of a 'Eurobond' (a mutual contingent liability), but sizeable gains in interest rates were not passed on to the troubled countries. Instead, loans were extended at rather punitive rates to avoid 'moral hazard' ('transfers') in the first place.
} 
available (i.e. not only guaranteed). 'The EU was once again grossly underprepared to deal with the burgeoning crisis' (Gocaj - Meunier 2013:247; see also Benczes 2011). Therefore, in March 2011, the European Council decided to establish a permanent stability mechanism, the ESM, replacing the EFSF from 2013 onwards (Verdun 2015). The ESMs lending capacity was set to $€ 500$ billion. Most of its subscribed capital came in the form of guarantees and 'callable capital', besides a paid-in part of $€ 80$ billion (Manasse 2011; Minenna - Aversa 2019). That is, a guarantee-based approach was maintained, along with the size of the overall rescue capacity. An innovation compared to the previous EFSF setting was the concept of private sector involvement (Christova 2011). It was envisaged so that in case of irreversible debt dynamics, the recipient state would have to start renegotiating its debts with private creditors. Although such an outcome remained very unlikely (as it was conditional on an official declaration of unsustainability by EU institutions), some further steps were taken to make way for private involvement. Since 2013, so-called Collective Action Clauses (CACs) have been included in new government securities with a maturity over 1 year, issued by any member state (ESM 2020a). These CACs foresee that a change in bond terms (such as restructuring) can happen if approved by a qualified majority of creditors at the levels of each bond series and all series combined.

In terms of tools, the ESM was at the start mandated to extend loans (with strict conditionality), and also to buy government bonds in primary markets (up to 50\% of the final issued amount to reduce the risk of a failed auction) (ESM 2020b). Interest rates of loans were decreased to some extent (by 100 basis points). Shortly after its creation, the ESMs powers were extended in July 2011, allowing the institution to recapitalize banks and make purchases in secondary markets (Christova 2011). The former tool was used to rescue Spanish banks in 2012, and Cyprus also entered a program thereafter in 2013. Apart from loans and indirect bank recapitalization, no other instruments have been used yet (ESM 2020b).

As it can be seen from the above, markets indeed pushed EMU leaders to adopt more farreaching bailout solutions amid a sustained euro area debt crisis. Schwendner et al. (2015) argue that a consolidation in sovereign bond markets ${ }^{3}$ can be attributed to the new rescue mechanisms. Similar conclusions are drawn by Kiss et al. (2019) who find that EFSF/ESM loans contributed to the observed decline in yield premia in the aftermath of the euro crisis. In contrast, Gödl and Kleinert (2016) establish that announcements of financial assistance and fiscal measures (as conditions of rescue packages) prompted no significant change in periphery bond yields (except for Ireland). These authors parallelly find that other events had significant effects (e.g. ECB action and separate country-specific episodes like the Greek 'haircut' in 2012). Changes in yields are the key focus of this paper. Our findings are presented in the next chapter, based on an event set covering the evolution of EMU bailout funds.

A recent debate about the ESM is related to its latest reform. At the end of 2019, Italy announced that it would seek changes in the approach regarding the amendment of the ESM Treaty, which had come to the last phase of approval (Fonte - Jones 2019; ANSA 2019). It is essentially this turmoil which has directed our attention to the ESM and its overhaul. The situation, resembling a deadlock, namely points to the fact that meaningful EMU reforms have stalled since 2014, due to different visions of the member states (Bénassy-Quéré et al., 2018; Minenna and Aversa, 2019). Italy's key fear is that new ESM rules may raise its debt servicing costs. Such an outcome would certainly hurt Italy,

\footnotetext{
${ }^{3}$ The end of negative correlations between daily changes of yields of core versus periphery countries.
} 
whose public debt-to-GDP ratio is the second largest in the euro area, at $137 \%$ in the third quarter of 2019 according to Eurostat (2020) data, surpassed only by a Greek ratio of $178 \%$. We close this chapter by reviewing the reform and the potential rationale for Italian doubts.

Changes in the ESM framework were initiated a couple of years ago when proposals like a nonpaper by then German Finance Minister Wolfgang Schäuble (2017) raised the question of debt restructuring. Schäuble suggested that ESM assistance should come with an automatic extension of bond maturities of the recipient state. Moreover, a mandatory debt restructuring mechanism should be laid down and used, if necessary, to restore debt sustainability. The non-paper also points to the need to modify CACs to facilitate private sector involvement in risk sharing.

Despite such proposals, current revisions do not include an automatic obligatory restructuring as a condition for ESM help (ESM 2020a). Amendments of CACs have, however, become a part of the reform, and these must be the main source of Italian concerns about rising yields. Current CACs are so-called 'double-limb CACs'. As already mentioned, they require two separate majorities to approve a change in bond terms: one at the level of each series and one at the level of all series combined (ESM 2020a). This feature benefits 'holdout' investors who can block a debt restructuring by acquiring majority in a single series. Similar CACs have caused misery during the 2012 Greek haircut when debt burdens from 18 series (out of 35) could not be eased due to 'holdout' investors (Bénassy-Quéré et al. 2018).

To prevent such an outcome, 'single-limb' CACs are envisaged by the reform. These 'allow the majority vote to take place at the level of all (...) series combined, without the need for a majority at the level of the holders of each individual series' (ESM 2020a). The amendment makes debt restructuring (if needed) clearly easier. This can, in turn, decrease the attractiveness of government bonds, especially in the case of highly indebted sovereigns like Italy. Italian critics argue that higher yields will follow, making it 'more likely that Italy will have to restructure or even default on its debt' (Fonte - Jones 2019). Note, however, that a reverse interpretation would also make sense as an easier debt restructuring might favour investors as well. Most bondholders would be 'happy' with securing a deal smoothly if that were the only way to get any payments (to minimize inevitable losses). Still, from a forward-looking perspective, fewer chances for strategic behaviour (less bargaining power) may discourage investors, especially bigger ones. Actual market reactions are checked in the next chapter.

Other key points of the ESM reform include a backstop for the Single Resolution Fund (SRF) and enhancing the effectiveness of precautionary credit lines (PCLs) (Howarth - Spendzharova 2019; Bauer - Herz 2020). A pillar of the banking union, the SRF is an EMU-level fund for the resolution of failing banks. Granting a backstop is aimed at strengthening its stabilization function. Notwithstanding, such a commitment will necessarily put a strain on the resources of the ESM, even though potential ESM loans are capped (ESM 2020a). As regards PCLs, the innovation lies in more standardization. PCL requests will be processed on the basis of standardized eligibility criteria, increasing speed and transparency. To the best of our knowledge, neither the backstop function nor the change in PCLs have been challenged by recent Italian critics.

Italy's reservations have had a remarkable impact on the approval process. Although in December 2019, the Eurogroup agreed in principle on a revised ESM Treaty text, its final adoption by national parliaments was postponed (originally until spring 2020). It was not by accident that in January 2020, Eurogroup President Mário Centeno hinted at the importance of a 'package approach' (Centeno 2020a). Italy namely stressed that such a solution could make the ongoing ESM reform more feasible. A 'package' here refers to the need for advancing other reforms 
parallelly. An EMU-wide bank deposit guarantee, a common unemployment insurance scheme and progress on a eurozone budget are among those preferred by Italy (Fonte - Jones 2019). However, these plans are much less advanced as they continue to prompt even more disagreement among the members. At the time of writing this paper, EMU states are temporarily 'exempted' from solving this particular impasse on ESM as the coronavirus outbreak has rewritten the agenda. Final agreement on the reform has been postponed indefinitely (Centeno 2020b).

After long talks, EU leaders in July 2020 agreed on the new budget of the union and further funds to deal with the fallout of the COVID-19 pandemic. In total, these arrangements will provide the community with $€ 750$ billion in grants and loans, and most importantly, the money will also be raised by the European Commission as a joint obligation of the member states (ET 2020). The agreement came after cut-throat debates, largely driven by the 'frugal four' (Netherlands, Austria, Denmark and Sweden) who firmly opposed the idea of mutualized debt (Politico 2020). Time will tell whether the package can relieve the disappointment of Italy and other hard-hit countries over European solidarity. The pandemic also puts the post-2010 institutional reforms to a special test.

In what follows, we examine whether policy steps shaping the EMU bailout framework had an impact on sovereign bond yields in the eurozone periphery after the onset of the debt crisis.

\section{EMPIRICAL ANALYSIS}

In the empirical part of our paper, we analyse the impact of EFSF/ESM-related policy announcements on government bond yields in the periphery. To do so, we create a panel comprising Italy, Spain, Portugal and Ireland $(i=4)$ over the period 2010-2020. We disregard Greece because of a notable shrinkage in its marketable debt, implying a less reliable reflection of investor sentiment. We assess market reactions by employing an event study approach, explaining the change in bond yields in the panel with an event dummy for our event set.

\subsection{Data and variables}

We use benchmark government bond yields on different maturities (1, 5 and 10 years). Benchmark yields enable us to compare roughly similar securities in terms of maturity, although the shift from one bond to another as benchmark might lead to an unexplained rise in yields. Fig. 1 provides an overview of the respective yields since the start of the euro crisis. It depicts the extraordinary increase during the turmoil and the subsequent moderation (as discussed in Chapter 2). Daily observations cover every working day between January 2010 and January 2020 $(t=2,625$, implying a total number of data points of $N=10,500){ }^{4}$

Yields in our dataset are not stationary. Thus, we calculate first differences, i.e. daily changes of yields (dyield) for each maturity. Augmented Dickey-Fuller tests show that these new time series contain no unit roots. First differences eliminate the problem of changing benchmarks as well, given that any unexplained rise due to such shifts becomes less apparent. Furthermore, using first differences later allows us to disregard fundamental determinants of yields which do not change in the very short run (Gödl - Kleinert 2016).

\footnotetext{
${ }^{4}$ There are no data on bonds with 1-year maturity for Spain up until 8 August 2011 as no benchmark yields are provided by Bloomberg in this case, and no other bonds could be used as a substitute, either.
} 

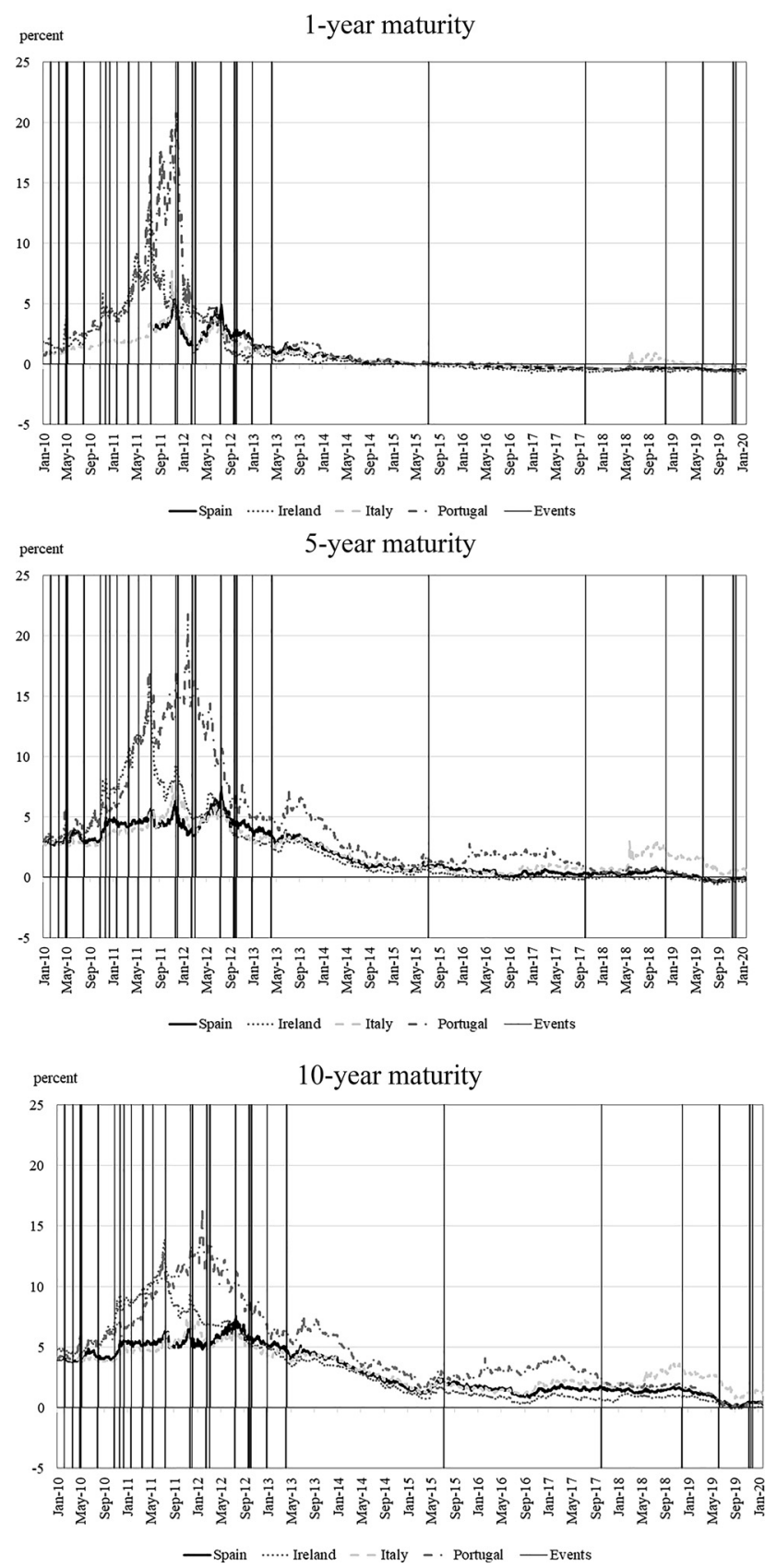

Fig. 1. Government bond yields (1,5 and 10-year maturities) and dates of events. Source: authors, based on Bloomberg 
For model calculations, we create a set of announcements related to EFSF/ESM. This set embodies the dynamics of policy developments discussed in Chapter 2. That is, it covers all relevant institutional changes and actions, ranging from early indications of a bailout scheme in 2010 up until the 2018-2019 reform. In total, we consider 29 events as shown in Fig. 1. (See Annex for a detailed list.) Note that the set does not contain country-specific fiscal announcements and ECB decisions as these are not directly connected to our scope. Possible effects of such events are captured by control variables discussed below.

We create a dummy variable for our event set (Events). It equals to 1 on the days of the announcements as well as on the days preceding and following them. On all other days, the value of the dummy is 0 . Surrounding days are taken into account as anticipated and lagged effects are more likely to be captured this way. That is, we measure the potential contemporaneous impact of selected events on yields in 3-day 'time windows'.

As for control variables, we collect several indicators, some of which have different values for each periphery country, while others are common indicators. We start with 3 country-specific indicators: uncertainty index (Unc_index), Bloomberg political risk index (BBG_pol_risk) and periphery Credit Default Swap (CDS) data (PER_CDS), all provided by Bloomberg. Note that we use 5-year contracts for CDS in the case of each bond maturity as others were not liquid at all times for all countries. In order to proxy underlying euro area processes and global risk sentiments, we select 7 common variables. These are the following: CBOE Volatility index, commonly referred as VIX index (VIX_index), Citi macro risk indicator (Citi_macro), Citi short-term indicator (Citi_short) and Citi inflation (CPI) surprise index (Citi_CPI) for the eurozone, along with EU uncertainty index (EU_unc_index). In addition, German benchmark yields of the respective maturities (Ger_XY) and the so-called 'inflation breakevens' (CPI_breakeven) are added. The former is regarded as the 'risk-free' rate. The latter embodies information about the market pricing of inflation-linked bonds, i.e. it signals changing market perceptions of future inflation rates. In the case of daily data, first differences are used (in accordance with the time series of bond yields), while monthly indicators, such as Citi-indices, political risk and uncertainty indices, remain unchanged.

As an indicative robustness check, we resort to the 'popularity' of Google keywords 'EFSF/ ESM'. This may help us double-check if there was increased attention to bailout funds in the respective periods (which in turn could have contributed to the observed changes in bond yields). We rely on Google's own scale for measuring 'popularity'. (The scale ranges from 1 to 100 , with higher values indicating more searches for a keyword. The underlying methodology is accepted for the purposes of this paper.) As 'popularity' of these words potentially overlaps, we use the form 'ESM OR EFSF' in the first place, but we look at separate popularity indices, as well. Note, however, that values are only available on a monthly basis, so differences in the case of consecutive events within the same month are not reflected.

\subsection{Model}

In the literature, modelling the impact of policy announcements is common as it may be interpreted easily, even though the method is quite limited in capturing longer-term effects. Our model is based on Falagiarda and Reitz (2015). These authors employed a similar set of panel data to examine the impact of the ECBs quantitative easing programs. They compared the so-called 'event days' with the rest of the trading days by applying an event dummy in a linear regression. While 
their event set was built to measure the relative importance of unconventional monetary policy measures introduced by the ECB, we applied this method to events related to EFSF/ESM.

Thus, we estimate the following model (Eq. (1)):

$$
\text { dyield }_{i, t}=\alpha+\beta_{1} \text { Events }_{t}+\boldsymbol{\beta}_{\mathbf{2}} \boldsymbol{X}+\boldsymbol{\beta}_{3} Z+\varepsilon_{i, t}
$$

where dyield is the first difference of the respective government bond yield of country $i$ at time $t$. We repeat the same regression for each maturity. Remember that Events is a dummy for EFSF/ ESM announcements as described earlier. This is a common variable with the same events for all countries in our panel. $X$ and $\boldsymbol{Z}$ are sets of control variables, with $\boldsymbol{X}$ being country-specific, while $\boldsymbol{Z}$ not. $\boldsymbol{X}$ includes PER_CDS, Unc_index and BBG_pol_risk, and $\boldsymbol{Z}$ comprises the rest of our control variables. (First differences are applied in the case of daily data. As part of $\boldsymbol{Z}$, German yields are of the same maturity as periphery yields in the respective equation.) Intercept $\alpha$ is common for all countries (Chow test shows that no country-specific fixed effects are needed in the model $).{ }^{5}$ Finally, $\varepsilon$ denotes the error term.

Our approach is similar to that of Gödl and Kleinert (2016) and Kiss et al. (2019) as both studies apply variations of the event study method and regressions with dummies related to EFSF/ESM. Nonetheless, we resort to a single, more detailed and comprehensive event set covering the evolution of bailout policies. This goes beyond focussing exclusively on the fact whether financial assistance was received by a country or not (Kiss et al. 2019). We also overcome limitations arising from a very small number of events of separate types, and we pool announcements about EMU bailout funds exclusively (two features different from Gödl and Kleinert (2016)).

\section{3.. Results and discussion}

Our estimations show that the announcements had a significant negative impact on the daily change in bond yields of EMU periphery countries between January 2010 and 2020 (Tables 1-3). In other words, news about the European bailout funds tended to contribute to the moderation of contemporaneous sovereign yields in the periphery after the outbreak of the euro crisis. After several iterations, we omitted most macro indices as they did not improve the explanatory power of the models. Thus, the final models include the daily change in the CDS price of the respective periphery country and the daily changes in the VIX index and the benchmark German government bond yields. The latter two proxy variables allow us to capture global, regional trends affecting yields, while CDS is supposed to reflect perceptions of default risk.

In the case of 1-year government bond yields, we find that the Events dummy is significant at every conventional significance level $(P<1 \%)$. Therefore, we may establish that EFSF/ESM announcements significantly decreased daily differences of 1-year sovereign yields within the 3day 'time windows', by approximately 5 basis points on average each time. This practically means that news on bailout funds helped to avert further rises in periphery yields or contributed to their decrease on the surrounding days. Thus, markets seem to have reacted positively (at least) in the short run. As regards our control variables, it is interesting to look at the change in 1-year German yields: a negative coefficient suggests that yields of the periphery and Germany

\footnotetext{
${ }^{5}$ Note that if Events turns out to be significant, dyield is shifted (ceteris paribus) on those days which are in a 3-day 'time window' (i.e. if Events $=1)$. This technically implies $\left(\alpha+\beta_{1}\right)$ as the intercept, but $\alpha$ itself is time-invariant.
} 
Table 1. Panel output 1: Impacts of EFSF/ESM-related events on periphery bond yields on 1-year maturity

\begin{tabular}{|l|c|c|c|c|}
\hline \multicolumn{5}{|c|}{ Dependent variable: dyield_1Y } \\
\hline Variables & Coefficient & Std. error & $t$-Ratio & $P$-value \\
\hline constant & 0.000 & 0.002 & 0.055 & 0.956 \\
\hline Events & -0.046 & 0.011 & -4.165 & $3.147 \mathrm{e}-05^{* * *}$ \\
\hline d_PER_CDS & 0.001 & 0.000 & 15.848 & $<2.2 \mathrm{e}-16^{* * *}$ \\
\hline d_VIX_index & 0.004 & 0.001 & 3.173 & $0.002^{* * *}$ \\
\hline d_GER_1Y & -0.475 & 0.095 & -5.006 & $5.642 \mathrm{e}-07^{* * *}$ \\
\hline
\end{tabular}

$N=10,500, F$-statistic: $85.55, P$-value: $<2.22 \mathrm{e}-16 * * * R$-square: 0.03 .

Significance codes: '***' 0.01 ' $* *$ ' 0.05 .

Notes: dyield_XY: daily change in bond yields (X-year maturity) of the respective periphery state; Events: dummy for the EFSF/ESM-specific event set (1 for the day of an announcement, the preceding and the following day, 0 otherwise); $d \_P E R \_C D S$ : daily change in CDS of the respective periphery state; $d \_V I X \_i n d e x:$ daily change in VIX index; $d_{-} G E R \_X Y$ : daily change in bond yields (X-year maturity) of Germany.

Source: authors.

Table 2. Panel output 2: Impacts of EFSF/ESM-related events on periphery bond yields on 5-year maturity

\begin{tabular}{|l|c|c|c|c|}
\hline \multicolumn{5}{|c|}{ Dependent variable: dyield_5Y } \\
\hline Variables & Coefficient & Std. error & t-Ratio & P-value \\
\hline constant & -0.001 & 0.001 & -0.543 & 0.588 \\
\hline Events & -0.024 & 0.008 & -3.110 & $0.002^{* * *}$ \\
\hline d_PER_CDS & 0.001 & 0.000 & 26.231 & $<2.2 \mathrm{e}-16^{* * *}$ \\
\hline d_VIX_index & 0.005 & 0.001 & 6.801 & $1.097 \mathrm{e}-11^{* * *}$ \\
\hline d_GER_5Y & -0.127 & 0.034 & -3.766 & $1.671 \mathrm{e}-4^{* * *}$ \\
\hline
\end{tabular}

$N=10,500, F$-statistic: $216.97, P$-value: $<2.22 \mathrm{e}-16^{* * *}, R$-square: 0.08 .

Significance codes: '***' 0.01 ' $* *$ ’ 0.05 .

Notes: dyield_XY: daily change in bond yields (X-year maturity) of the respective periphery state; Events: dummy for the EFSF/ESM-specific event set (1 for the day of an announcement, the preceding and the following day, 0 otherwise); $d \_P E R \_C D S$ : daily change in CDS of the respective periphery state; $d \_V I X$ index: daily change in VIX index; d_GER_XY: daily change in bond yields (X-year maturity) of Germany.

Source: authors.

were negatively correlated in the last 10 years. This points to the role of German securities as 'safe assets' which investors rush to buy in times of turmoil in the EMU periphery.

Regarding 5-year yields, the Events dummy also proves to be significant at a $1 \%$ level. Nonetheless, the estimated coefficient is smaller. In the case of 10 -year bonds, the dummy is 
Table 3. Panel output 3: Impacts of EFSF/ESM-related events on periphery bond yields on 10-year maturity

\begin{tabular}{|l|c|c|c|c|}
\hline \multicolumn{5}{|c|}{ Dependent variable: dyield_10Y } \\
\hline Variables & Coefficient & Std. error & $t$-Ratio & P-value \\
\hline constant & -0.001 & 0.001 & -0.983 & 0.326 \\
\hline Events & -0.014 & 0.006 & -2.464 & $0.014^{* *}$ \\
\hline d_PER_CDS & 0.001 & 0.000 & 26.839 & $<2.2 \mathrm{e}-16 * * *$ \\
\hline d_VIX_index & 0.006 & 0.001 & 10.232 & $<2.2 \mathrm{e}-16^{* * *}$ \\
\hline d_GER_10Y & 0.132 & 0.023 & 5.752 & $9.054 \mathrm{e}-09 * * *$ \\
\hline
\end{tabular}

$N=10,500, F$-statistic: $216.29, P$-value: $<2.22 \mathrm{e}-16^{* * *}, R$-square: 0.08 .

Significance codes: ' $* * *$ ' $0.01^{\prime} * *$ ’ 0.05 .

Notes: dyield_XY: daily change in bond yields (X-year maturity) of the respective periphery state; Events: dummy for the EFSF/ESM-specific event set ( 1 for the day of an announcement, the preceding and the following day, 0 otherwise); $d \_P E R \_C D S$ : daily change in CDS of the respective periphery state; $d \_V I X \_i n d e x:$ daily change in VIX index; $d \_G E R \_X Y$ : daily change in bond yields (X-year maturity) of Germany.

Source: authors.

again significant at a threshold close to $1 \%$. The impact is the smallest in this case: we may identify a 1-basis point average decline attributed to our events. In sum, we can conclude that EFSF/ESM-related announcements came with a contemporaneous moderation in periphery bond yields in the aftermath of the euro crisis. The coefficient of German yields (d_GER_XY) remained negative in the case of 5-year maturities, but interestingly, it switched to positive for 10 -year bonds. This may reveal that the role of German bonds as a 'safe asset' is most evident in the short to medium term, while long-term maturities tend to reflect expectations of intra-EMU convergence.

Note that our conclusions do not change if we only use the events of the most turbulent times of the euro crisis (i.e. 2010-2013, see Events 1-22 in Annex). This iteration allows us to check the impact of the core institutional progress (up until the ESM commenced its operations), with no regard to the recent reform. Table 4 sums up the coefficients of Events for this shorter period of

Table 4. Coefficients of events dummy using a reduced event set (2010-2013)

\begin{tabular}{|l|c|c|}
\hline Maturity & Coefficient & P-value \\
\hline 1-year & -0.061 & $0.008^{* * *}$ \\
\hline 5-year & -0.031 & $0.029 * *$ \\
\hline 10-year & -0.019 & 0.059 \\
\hline
\end{tabular}

Notes: Pooled models $(N=3,636)$. Estimation of Equation (1) for each maturity using a reduced event set (Events 1-22 in Annex) and the same control variables as given in Tables 1-3.

Source: authors. 
time. Results show that until mid-2013, events related to the EMU bailout funds had even slightly stronger impacts on bond yields, especially in the case of 1-year maturity.

Although the overall explanatory power of our models could be upgraded, this is not key here insofar as our Events dummy is significant even together with strong indicators of default risk and market uncertainty (as control variables). So, we deem that our results provide useful insights, especially what regards different maturities. According to the literature, short-term yields are more likely to be affected by market sentiments and expectations about monetary policy decisions, while long-term yields reflect long-run structural factors. The latter are also more likely to be influenced by quantitative easing programs, by nature. These stylised facts are reflected in our results as well. Our outputs suggest that markets were calmed by EFSF/ESM announcements mostly in the case of shorter maturities. This is also in line with the background described in Chapter 2. It can thus be assumed that policy steps leading up to the creation and usage of capped funds were judged by markets mostly as a temporary fix. That is, investor confidence returned in the case of short-term periphery bonds, but they were less convinced that changes at hand would help to end divergence among eurozone countries in the long run. This may be due to the incremental and largely uncertain nature of the institutional progress, along with doubts on the overall size and structure of the dedicated funds. An alternative explanation is that the ECBs QE programs may have muted the impact of the institutional changes in the case of 10-year maturities.

Regarding the robustness of our results in Tables 1-3, we carry out two types of alternative estimations. First, choosing and rotating different sets of the control variables do not change the significance levels ( $P$-values) of the Events dummy in a sizable manner, on either of the maturities involved. Coefficients remain negative and they do not change substantially. Second, we substitute the event set with Google popularity statistics, and we find that 'popularities' of EFSF and ESM keywords prove to be significant. It is a thought-provoking result, raising questions that go beyond the scope of our paper (e.g. how market sentiments are indeed reflected in Google searches). Nevertheless, we argue that this alternative outcome confirms our results, namely that markets reacted positively to the news on EFSF/ESM. Put otherwise, the observed moderation in periphery bond yields is less likely to be attributable to an unknown, omitted variable. This is because searches for EFSF/ESM must have been prompted by actual events, and delivered information about additional funds for troubled EMU member states.

As for the evolution of yields between November 2019 and January 2020, Italian concerns about the ESM overhaul seem not to be underpinned. That is, we could not observe an obvious unilateral rise in sovereign bond yields for Italy (neither for Greece with similarly high debts). This can be due to the fact that the ESM reform does not include an automatic obligatory debt restructuring as a condition for financial assistance. Although the modification of CACs can be regarded as disadvantageous for private investors in future cases, Italian fears of capital flight did not come true during the period of the debate.

Our results are in line with those of Schwendner et al. (2015) and Kiss et al. (2019) as we also find that the EFSF/ESM played a significant role in decreasing periphery bond yields, at least what regards prompt market reactions. Our finding adds to the literature by demonstrating that the significant relationship can also be established when considering a broad set of EFSF/ESMrelated events (not only disbursements of bailout loans themselves). This result may be a common ground for further debates on the ESM. That is, any proposals should be assessed on the basis of whether they help preserve the contribution of the ESM to financial stability. 


\subsection{Limitations}

Our methodology has the usual limitations of event study methods, which do not allow assessing longer-term impacts of events and are not suited to uncover connections between explanatory variables. Therefore, we could just offer limited insights into the underlying factors of the evolution of periphery bond yields. As suggested earlier, a lasting moderation after 2012 could mostly result from ECB policies, i.e. quantitative easing, which practically offered unlimited last resort for members in need. However, this paper had a short-term empirical focus as it sought to investigate contemporaneous market reactions to the creation and usage of EMU rescue funds. These short-term insights are also relevant from a financial stability perspective.

In addition, note that event study outcomes may be sensitive to changes in the event set. In this paper, we strove to reach a reasonable coverage of EFSF/ESM-related events.

We shall add two further remarks to the regressions above. First, as we have just noted, the persistence of the impact could not be handled in this type of model. Other factors also influence bond yields, such as particular data releases, deterioration in investment environment or business confidence, changes in domestic policies, shifts in the global economy, etc. That is, the direct effects of announcements examined in this paper are likely to disappear after a couple of days. According to our calculations for the event set used in this paper, the effect lasted on average for 2-4 days after the announcement, with little heterogeneity in the different countries ( 2 days in Italy, 3 in Portugal, Spain and Ireland). (In this respect, the date of disappearance is the first day when the yield rose for the first time after the announcement.)

Second, although the institutional reform of the ESM received serious criticism from some Italian politicians at the end of 2019 , we had few data points to assess these statements alone. Thus, we could only provide a qualitative assessment as part of our paper's broader context. With more hindsight, however, the impacts of the reform (including the introduction of 'singlelimb' CACs) can be evaluated separately in the future. A question whether new CACs provoke higher yields in times of market turbulence could only be answered later, too.

\section{CONCLUSIONS}

This paper examined the relationship between policy announcements about the EMU bailout framework and contemporaneous sovereign bond yields. The relevance of the topic is underlined by concerns about the recent ESM overhaul. As in December 2019, Italy (one of the most indebted countries of the euro area) voiced fears of a resulting increase in its bond yields, the larger issue of pending EMU reforms came under the spotlight again.

Therefore, we deemed it essential to investigate the background of the concerns and more broadly, the role of Europe's bailout arrangements in affecting sovereign yields. An event study approach and panel regressions were applied for this purpose. Our aim was to create a comprehensive set of major EFSF/ESM-related events after the outbreak of the euro crisis. To that end, we reviewed the process leading up to the creation of a permanent bailout fund for the eurozone (the ESM), highlighting different views of two groups of member states on intra-area risk sharing. At the onset of the crisis, the currency union lacked a common framework and funds for financial assistance to its members. Soaring periphery bond yields then forced the EMU to take action, and among other steps, a bailout fund (with a capped lending capacity of $€ 500$ million) was created and entrusted with certain intervention powers. Our event set took 
stock of the related institutional progress and 'rescue loans' extended to distressed countries. Potential impacts on periphery bond yields were examined in 3-day 'time windows' surrounding each announcement.

Our empirical findings show that EFSF/ESM-related events significantly decreased government bond yields in the eurozone periphery. That is, the creation of an EMU bailout framework is likely to have contributed to preserving financial stability at critical moments. However, we could establish that yields of sovereign bonds with longer maturities reacted less strongly. This result might be attributed to quantitative easing programs and/or the relative scepticism of investors regarding the longer-term effects of capped bailout arrangements. In this respect, the possibility of unlimited ECB action must have been a decisive factor, facilitating a moderation in yields after 2012 .

As for the period between late 2019 and early 2020, when debates on the ESM reform were high on the agenda, we could observe no obvious unilateral increase in bond yields for Italy. Time will tell whether a possibly less favourable position of private investors (due to new CACs) prompts any capital flight and a rise in periphery yields. Nonetheless, a 'package approach' stressed by Italy may well need to be taken into account. That is, EMU reforms should at best come together in order to reduce the chance of unintended outcomes for the most fragile members. A consensus on the architecture of the euro has perhaps never been as important as in times of the coronavirus pandemic and its economic fallout. An impasse on reforms like that of the ESM or a common deposit insurance fund may now seem to be blurred as EMU leaders have to deal with a huge fall in economic activity. After several months of harsh debates, the 'frugal four' led by the Netherlands conceded to a $€ 750$ billion package, which will see EU countries take on joint obligations for the purpose of fighting the COVID-19 crisis. To fully benefit from this deal, structural challenges of the euro area will also need to be addressed in the medium term.

\section{REFERENCES}

Acharya, V. - Drechsler, I. - Schnabl, P. (2014): A Pyrrhic Victory? Bank Bailouts and Sovereign Credit

Risk. The Journal of Finance 69(6): 2689-2739.

ANSA (2019): Conte Defends ESM, Tells Opponents to Say if They Want Euro Exit. ANSA News Agency.

https:/www.ansa.it/english/news/2019/12/11/conte-defends-esm-tells-opponents-to-say-if-want-euro-

exit_5490fe69-6c76-4fce-9b97-b851408c0224.html, accessed 11 November 2019.

Bauer, C. - Herz, B. (2020): Reforming the European Stability Mechanism. Journal of Common Market Studies 58(3): 636-653.

Bénassy-Quéré, A. - Brunnermeier, M. - Enderlein, H. - Farhi, E - Fratzscher, M. - Fuest, C - Gourinchas, P.-O. - Martin, P. - Pisani-Ferry, J. - Rey, H. - Schnabel, I. - Véron, N., Weder di Mauro, B. Zettelmeyer, J. (2018): Reconciling Risk Sharing With Market Discipline: A Constructive Approach to Euro Area Reform. CEPR Policy Insight No. 91.

Benczes, I. (2011): Az európai gazdasági kormányzás előtt álló kihívások. A hármas tagadás lehetetlensége [Challenges of European Economic Governance. The Impossible Trinity of Denial]. Economic Review 58: 759-774. 
Centeno, M. (2020a): Remarks by Mário Centeno following the Eurogroup Meeting of 20 January 2020. https:/www.consilium.europa.eu/hu/press/press-releases/2020/01/20/remarks-by-mario-centenofollowing-the-eurogroup-meeting-of-20-january-2020/, accessed 12 March 2020.

Centeno, M. (2020b): Remarks by Mário Centeno following the Eurogroup Meeting of 16 March 2020. https:/www.consilium.europa.eu/hu/press/press-releases/2020/03/16/remarks-by-mario-centenofollowing-the-eurogroup-meeting-of-16-march-2020/, accessed 09 April 2020.

Chang, M. - Leblond, P. (2015): All In: Market Expectations of Eurozone Integrity in the Sovereign Debt Crisis. Review of International Political Economy 22(3): 626-655.

Christova, A. (2011): The European Stability Mechanism: Progress or missed opportunity? Baltic Journal of European Studies 1(2): 49-58.

De Grauwe, P. (2012): The Governance of a Fragile Eurozone. The Australian Economic Review 45(3): 255268.

De Grauwe, P. (2013): Design Failures in the Eurozone - Can They be Fixed? European Economy Economic Papers 491.

De Grauwe, P. (2018): Political Economy of Deconstructing the Eurozone. In: De Grauwe, P.: Economics of Monetary Union. Oxford: Oxford University Press, 12th ed., pp. 149-164.

Delpla, J. - Weizsäcker, J. von (2010): The Blue Bond Proposal. Bruegel Policy Brief No. 2010/03.

Draghi, M. (2012): Speech by Mario Draghi, President of the European Central Bank at the Global Investment Conference in London, 26 July 2012. European Central Bank Release. https://www.ecb.europa. eu/press/key/date/2012/html/sp120726.en.html, accessed 02 February 2020.

ET (2020): Stimulus Package Breaks New Ground in European Unity, 27 Nations to Share Financial Burden. The Economic Times 21 July. https:/economictimes.indiatimes.com/news/international/business/ stimulus-package-breaks-new-ground-in-european-unity-27-nations-to-share-financial-burden/ articleshow/77089312.cms, accessed 30 August 2020.

Eichengreen, B. (2010): The Euro: Love It or Leave It? VOX CEPR Policy Portal 04 May.

ESM (2020a): ESM Treaty Reform Explainer. https://www.esm.europa.eu/about-esm/esm-treaty-reformexplainer, accessed 02 February 2020.

ESM (2020b): Lending Toolkit. https://www.esm.europa.eu/assistance/lending-toolkit\#lending_toolkit, accessed 07 December 2020.

Eurostat (2020): General Government Gross Debt - Quarterly Data. https://ec.europa.eu/eurostat/web/ products-datasets/-/teina230, accessed 30 August 2020.

Falagiarda, M. - Reitz, S. (2015): Announcements of ECB Unconventional Programs: Implications for the Sovereign Spreads of Stressed Euro Area Countries. Journal of International Money and Finance 53: 276-295.

Fonte, G. - Jones, G. (2019): Italy PM Defends Reform of Eurozone Bailout Fund but Seeks Concessions. CNBC Online News 2 December. https://www.cnbc.com/2019/12/02/reuters-america-update-4-italypm-defends-reform-of-euro-zone-bailout-fund-but-seeks-concessions.html, accessed 02 February 2020.

Giordano, R. - Pericoli, M. - Tommasino, P. (2013): Pure or Wake-Up-Call Contagion? Another Look at the EMU Sovereign Debt Crisis. Bank of Italy Temi di discussione (Economic Working Papers) 904.

Gocaj, L. - Meunier, S. (2013): Time Will Tell: The EFSF, the ESM, and the Euro Crisis. Journal of European Integration 35(3): 239-253.

Gödl, M. - Kleinert, J. (2016): Interest Rate Spreads in the Eurozone: Fundamentals or Sentiments? Review of World Economics/Weltwirtschaftliches Archive 152(3): 449-475.

Howarth, D. - Spendzharova, A. (2019): Accountability in Post-Crisis Eurozone Governance: The Tricky Case of the European Stability Mechanism. Journal of Common Market Studies 57(4): 894-911. 
Kilponen, J. - Laakkonen, H. - Vilmunen, J. (2012): Sovereign Risk, European Crisis Resolution Policies and Bond Yields. International Journal of Central Banking 11(2): 285-323.

Kiss, G. D. - Csiki, M. - Varga, J. Z. (2019): Comparing the IMF and the ESM Through Bond Market Premia in the Eurozone. Public Finance Quarterly 2019(2): 277-293.

Manasse, P. (2011): The Trouble with the European Stability Mechanism. VOX CEPR Policy Portal 5 April. Mehrling, P. (2000): The State as Financial Intermediary. Journal of Economic Issues 35(2): 365-368.

Micossi, S. - Carmassi, J. - Peirce, F. (2011): On the Tasks of the European Stability Mechanism. CEPS Policy Brief No. 235.

Minenna, M. - Aversa, D. (2019): A revised European Stability Mechanism to Realize Risk Sharing on Public Debts at Market Conditions and Realign Economic Cycles in the Euro Area. Economic Notes by John Wiley \& Sons 48(1).

Pisani-Ferry, J. (2010): Euro-Area Governance: What Went Wrong? How to Repair It? Bruegel Policy Contribution 2010(05).

Politico (2020): Merkel and Conte Warn 'Frugal Four' Against Cuts to EU Corona Fund. 15 July. https:// www.politico.eu/article/angela-merkel-giuseppe-conte-warn-frugal-four-eu-recovery-fund/, accessed 30 August 2020.

RTE (2020): Eurogroup Chief Warns of Single Currency Break-up if Disputes Aren't Resolved. 31 March https://www.rte.ie/news/europe/2020/0331/1127594-euro-zone-coronoavirus-single-currency/, accessed 09 April 2020.

Schäuble, W. (2017): Non-Paper for Paving the Way Towards a Stability Union. Proposal for the Eurogroup (October 2017). http://www.astrid-online.it/static/upload/non-/non-paper_schauble.pdf, accessed 02 February 2020.

Schwendner, P. - Ott, T. - Schüle, M. - Hillebrand, M. (2015): European Government Bond Dynamics and Stability Policies: Taming Contagion Risks. ESM Working Paper Series 2015(8).

Strauch, R. - Rojas, J. - O’Connor, F. - Casalinho, C. - Ramón-Laca Clausen, P. de - Kalozois, P. (2016): Accessing Sovereign Markets - The Recent Experiences of Ireland, Portugal, Spain, and Cyprus. ESM Discussion Paper Series 2.

Surányi, G. (2012): The Global Crisis: Have we Learned the Right Lessons? CASE Network E-Briefs 2012(7). Várnay, E. (2017): Az Európai Központi Bank a válságban - az OMT-ügy [The European Central Bank Amid the Crisis - The OMT Case]. In: Kálmán, J. (ed.): Állam - Válság - Pénzügyek [State - Crisis Finance]. Budapest: Gondolat, pp. 368-394.

Verdun, A. (2015): A Historical Institutionalist Explanation of the EU's Responses to the Euro Area Financial Crisis. Journal of European Public Policy 22(2): 219-237. 


\section{ANNEX}

\section{List of events}

\begin{tabular}{|c|c|c|}
\hline No. & Date & Short description \\
\hline 1 & 11.02 .2010 & $\begin{array}{c}\text { First indication of a possible intervention (statement of } \\
\text { EMU leaders) }\end{array}$ \\
\hline 2 & 25.03.2010 & Statement of prospect for EU-IMF loans to Greece \\
\hline 3 & 02.05 .2010 & $\begin{array}{l}\text { EU-IMF and Greece agree on bailout (Greek Loan } \\
\text { Facility) }\end{array}$ \\
\hline 4 & 09-10.05.2010 & Ecofin meeting, decision about EFSM/EFSF \\
\hline 5 & 04.08 .2010 & Start of EFSF fully functioning \\
\hline 6 & 28-19.10.2010 & $\begin{array}{c}\text { European Council (EC) decides to start consultations } \\
\text { on a permanent resolution mechanism }\end{array}$ \\
\hline 7 & 28.11.2010 & Agreement on assistance to Ireland using EFSM/EFSF \\
\hline 8 & $16-17.12 .2010$ & $\begin{array}{c}\text { EC launches Treaty revision procedure to incorporate a } \\
\text { permanent stability mechanism }\end{array}$ \\
\hline 9 & 25.01.2011 & Landmark EFSF bond auction to facilitate Irish bailout \\
\hline 10 & 24-25.03.2011 & $\begin{array}{c}\text { EC agrees on establishing the ESM as a permanent } \\
\text { bailout fund }\end{array}$ \\
\hline 11 & 16.05 .2011 & Agreement on assistance to Portugal using EFSM/EFSF \\
\hline 12 & 21.07.2011 & $\begin{array}{c}\text { Enhancement of EFSF/ESM powers (recapitalization of } \\
\text { banks, intervention in secondary markets) }\end{array}$ \\
\hline 13 & 11.29.2011 & $\begin{array}{l}\text { Agreement on using the EFSF for Partial Protection } \\
\text { Certificates issued together with the beneficiary } \\
\text { member state's bonds ( } 20-30 \% \text { protection) }\end{array}$ \\
\hline 14 & 09.12 .2011 & $\begin{array}{l}\text { EU leaders' statement on ESM to be brought into force } \\
\text { in July } 2012\end{array}$ \\
\hline 15 & 21.02.2012 & Agreement on second Greek rescue package \\
\hline 16 & 09.03.2012 & Agreement with creditors on Greek debt restructuring \\
\hline 17 & 20.07.2012 & $\begin{array}{c}\text { Loans approved for Spain to recapitalise banks, } \\
\text { utilizing ESM }\end{array}$ \\
\hline 18 & 27.09.2012 & Establishment of ESM \\
\hline 19 & 08.10 .2012 & ESM commences its operations after inaugural meeting \\
\hline 20 & 12.10.2012 & $\begin{array}{l}\text { First batch of paid-in capital was transferred by all ESM } \\
\text { member states }\end{array}$ \\
\hline 21 & 01.01 .2013 & \\
\hline
\end{tabular}

(continued) 


\section{Continued}

\begin{tabular}{|l|c|c|}
\hline No. & Date & Short description \\
\hline 22 & 12.04 .2013 & $\begin{array}{c}\text { Standardized CACs kick in for new government bonds } \\
(>1 \text { year maturity) }\end{array}$ \\
\hline 23 & 12.07 .2015 & Agreement on Cypriot rescue package \\
\hline 24 & 09.10 .2017 & $\begin{array}{c}\text { Eurogroup meeting, proposal of Schäuble on ESM and } \\
\text { debt restructuring }\end{array}$ \\
\hline 25 & 04.12 .2018 & $\begin{array}{c}\text { EC approves package of measures to further strengthen } \\
\text { the ESM }\end{array}$ \\
\hline 26 & 14.06 .2019 & $\begin{array}{c}\text { Announcement of Eurogroup broadly agreeing on } \\
\text { revised ESM Treaty }\end{array}$ \\
\hline 27 & 20.11 .2019 & $\begin{array}{c}\text { Italian Foreign Minister publicly rejects ESM reform that } \\
\text { 'crushes Italy' }\end{array}$ \\
\hline 28 & 12.12 .2019 & $\begin{array}{c}\text { Italian Premier tells Parliament ESM reform should be } \\
\text { adopted as part of wider financial reforms }\end{array}$ \\
\hline
\end{tabular}

Source: authors. Events (announcements and dates) are collected from literature quoted in Chapter 2 and double-checked by using official EU websites (European Commission/Council, ESM).

Note: Each date in the table is considered as part of a 3-day time window $(t-1, t, t+1)$ in order to capture effects of the unfolding event (e.g. anticipations, news and official acts). For 2-day events, preceding and subsequent days are also added accordingly.

Open Access. This is an open-access article distributed under the terms of the Creative Commons Attribution 4.0 International License (https://creativecommons.org/licenses/by/4.0), which permits unrestricted use, distribution, and reproduction in any medium, provided the original author and source are credited, a link to the CC License is provided, and changes - if any - are indicated. (SID_1) 